Article

\title{
Synthesis and Characterization of a Lignin-Styrene-Butyl Acrylate Based Composite
}

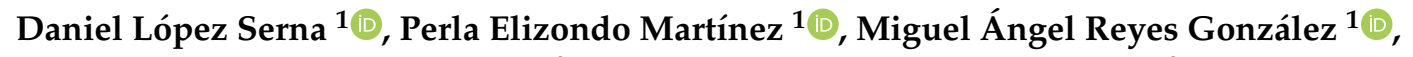 \\ Antonio Alberto Zaldívar Cadena ${ }^{2}$, Erasto Armando Zaragoza Contreras ${ }^{3}$ and \\ María Guadalupe Sánchez Anguiano 1,* \\ 1 Universidad Autónoma de Nuevo León, Facultad de Ciencias Químicas, Av. Universidad S/N, Cd. \\ Universitaria, 66455 San Nicolás de los Garza, N.L, México; dlslqi@gmail.com (D.L.S.); \\ perlaelizondomx1@gmail.com (P.E.M.); miguelangel138@hotmail.com (M.Á.R.G.) \\ 2 Universidad Autónoma de Nuevo León, Facultad de Ingeniería Civil, Av. Universidad S/N, Cd. \\ Universitaria, 66455 San Nicolás de los Garza, N.L, México; azaldiva70@gmail.com \\ 3 Centro de Investigación en Materiales Avanzados, S.C. Miguel de Cervantes No. 120, Complejo Industrial \\ Chihuahua, 31136, Chihuahua, Chih. México; armando.zaragoza@cimav.edu.mx \\ * Correspondence: maria.sanchezang@uanl.edu.mx
}

Received: 3 May 2019; Accepted: 20 June 2019; Published: 25 June 2019

check for updates

\begin{abstract}
In recent years, the pursuit of new polymer materials based on renewable raw materials has been intensified with the aim of reusing waste materials in sustainable processes. The synthesis of a lignin, styrene, and butyl acrylate based composite was carried out by a mass polymerization process. A series of four composites were prepared by varying the amount of lignin in 5, 10, 15, and $20 \mathrm{wt}$ \% keeping the content of butyl acrylate constant (14 wt.\%). FTIR and SEM revealed that the -OH functional groups of lignin reacted with styrene, which was observed by the incorporation of lignin in the copolymer. Additionally, DSC analysis showed that the increment in lignin loading in the composite had a positive influence on thermal stability. Likewise, Shore D hardness assays exhibited an increase from 25 to 69 when 5 and $20 \mathrm{wt}$ \% lignin was used respectively. In this same sense, the contact angle (water) measurement showed that the LEBA15 and LEBA20 composites presented hydrophobic properties (whit contact angle above $90^{\circ}$ ) despite having the highest amount of lignin, demonstrating that the interaction of the polymer chains with the $-\mathrm{OH}$ groups of lignin was the main mechanism in the composites interaction.
\end{abstract}

Keywords: lignin; polymer composites; thermal properties; hardness; contact angle

\section{Introduction}

Lignin, in conjunction with cellulose, is one of the most abundant biopolymers in nature. Lignin is obtained as a by-product from the wood pulp during the paper fabrication [1-3]. Due to its chemical structure, based in coniferyl, coumaryl, and sinapyl monomers randomly distributed and crosslinked, lignin has limited use in industrial scale processes [4,5]. Lignin is a natural polymer based in coniferyl, coumaryl, and sinapyl monomers, randomly distributed and crosslinked. It is an amorphous material and hydrophobic branched which has recently been used for industrial applications, in a variety of alternatives $[6,7]$.

During the last decades, a large number of studies have been presented on the potential use of lignin at the industrial level for the production of various materials, mainly as binder and dispersant $[8,9]$, although lignin is a large source of aromatic compounds. The research work at the laboratory level aims to use it for the development of high-value polymers [10-14] or for the production of biofuel; in both cases, the purpose is to reduce the emission of volatile organic compounds (VOC) and greenhouse 
gases, as $\mathrm{CO}_{2}$ [15-19]. Kasko et al. presented a review on the strategies to use lignin [20], where most of the research focuses on the methods developed for the synthesis of polymers from this biopolymer and its derivatives [20-22], giving a great value to the environmental benefit that entails the use of lignin as a raw material [23,24]. Other studies have focused on the application of lignin as a nanofiller [25] or in storage energy [26].

On the other hand, the study of the synthesis of compounds and nanocomposites through the grafting of lignin with acrylic monomers has been deepened $[27,28]$, which have served as the basis for studying the compatibility and reinforcement effect of lignin blend whit different monomers [29], as well as the analysis of the compatibility of mixtures of lignin with epoxy resins [30,31]. The research on the preparation of lignin with various polymeric materials with different applications has been studied from the viewpoint of matrix reinforcement with fibers or particles of different morphology [32-34]. The nature of the matrix varies from a synthetic polymer to a natural one, depending on the application [35-37]. It has been found that both the polymeric matrix and the reinforcement play an important role in the determination of the physicochemical properties of the composite materials in general [16,38-41]. Fatehi, et al. reported the modification of a polymer of lignin-g-styrene and its application for wastewater treatment and water purification, by introducing a sulfonate group in the polymer matrix that modifies the anionic charge [42].

Under this context, we present the synthesis of a new compound based on lignin, styrene, and butyl acrylate, obtained by a bulk free radical polymerization. In the mechanism suggested in Scheme 1 , styrene is added to the $-\mathrm{OH}$ groups of lignin through a free radical reaction. To understand the relationship between the lignin amount and the composite properties, the thermal properties, the contact angle, and the copolymer molecular weight, with and without lignin, were studied. The purpose was to deepen in the composite behavior to be able to visualize some potential applications; for example, as an adsorbent material to remove water pollutants, for synthetic wood, or for the absorption of hydrocarbons spills in water.

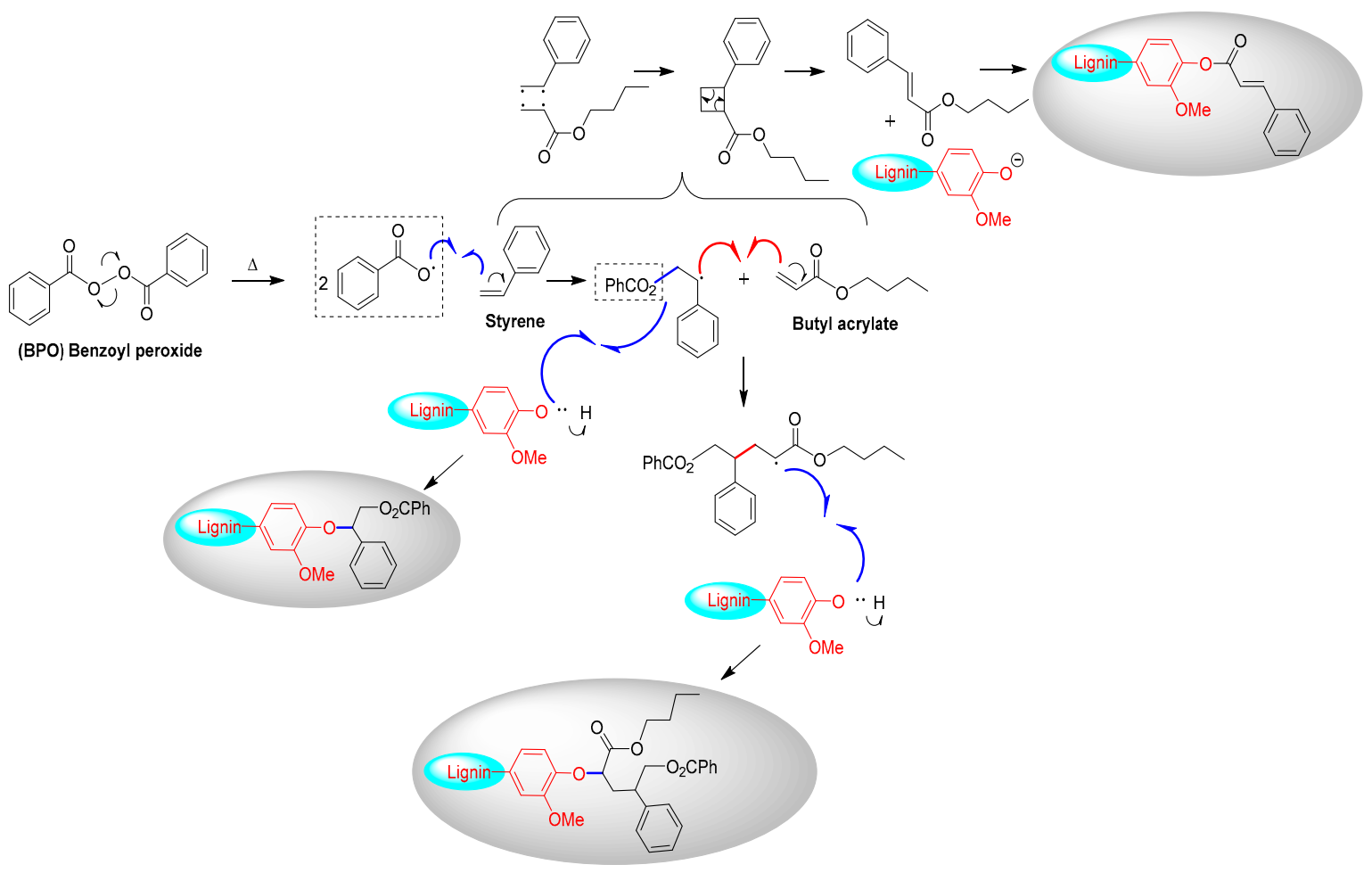

Scheme 1. Reaction mechanism for the chemical interaction between lignin and styrene-butyl acrylate copolymer. 


\section{Experimental}

\subsection{Materials}

Lignin Kraft (98\%, Sigma Aldrich, St. Louis, MO, USA) was dried in an oven for $24 \mathrm{~h}$ at $110^{\circ} \mathrm{C}$ to remove moisture, the main characteristics of lignin are $\mathrm{Mw} 28,000 \mathrm{~g} \mathrm{~mol}^{-1}$ and $\mathrm{Mn} 5000 \mathrm{~g} \mathrm{~mol}^{-1}$. Styrene monomer ( $98 \%$ DEQ, México), butyl acrylate ( $97 \%$ Sigma Aldrich), and benzoyl peroxide (99\% Sigma Aldrich). All reagents were used without further purification.

\subsection{Composite Synthesis}

The composite synthesis was performed by bulk free radical polymerization, mixing the defined amount of styrene (S), butyl acrylate (BA) and lignin, keeping the reagents total amount of $4.0 \mathrm{~g}$. Benzoyl peroxide $\left(\mathrm{C}_{14} \mathrm{H}_{10} \mathrm{O}_{4}\right)$ was fed at $1 \mathrm{wt} . \%$ with respect to the total amount of the reaction mixture. A total of five experiments was performed. Table 1 shows the relationship between lignin and styrene used. The polymerization time for all the experiments was $2 \mathrm{~h}$, at $90^{\circ} \mathrm{C}$, and maintaining a stirring speed of $1200 \mathrm{rpm}$. At the end of the established time, the materials were cooled rapidly in an ice bath (quenching). The products resulting from the experiments were identified as EBA for the material without lignin and LEBA for the materials containing lignin.

Table 1. Lignin and styrene quantity present in composites, with butyl acrylate (BA) constant in 14 wt.\%.

\begin{tabular}{cccc}
\hline Composite & Lignin [wt.\%] & Styrene [wt.\%] & BA/St ratio \\
\hline EBA & 0 & 86 & 0.16 \\
LEBA5 & 5 & 81 & 0.17 \\
LEBA10 & 10 & 76 & 0.18 \\
LEBA15 & 15 & 71 & 0.20 \\
LEBA20 & 20 & 66 & 0.21 \\
\hline
\end{tabular}

\subsection{Residual Styrene Analysis by HPLC}

To determine the reaction time effect on the incorporation of styrene in the composites, the amount of the residual monomer was analyzed. From the experiment LEBA15, $4.0 \mathrm{~g}$ of sample was taken at 5, 10, $15,30,45,60,75,90,135$, and $180 \mathrm{~min}$ of reaction, the sample was dispersed in methanol under stirring; then the composite was separated from the composite via centrifugation and the unreacted styrene was dissolved in methanol. Finally, the resulted solution was analyzed using a high-resolution liquid chromatograph (HPLC) (YL9100, Young Lin, Anyang, Korea), which has a UV detector (YL9160PDA, Young Lin), a column of $30 \mathrm{~cm} \times 4 \mathrm{~mm} \times 5 \mu \mathrm{m}$ (SUPELCOSIL LC-18-DB, SUPELCO, Sigma Aldrich), and as the mobile phase a methanol:water (65:35) solution. The samples were run at a flow rate of

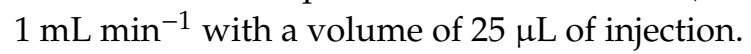

\subsection{Gel Permeation Chromatography Analysis}

In order to study the effect of the nitrogen atmosphere in the polymerization process, the synthesis of the copolymer EBA under nitrogen and air was achieved. The obtained copolymers were analyzed by gel permeation chromatography (GPC) (YL900GPC, Young Lin) using HPLC grade tetrahydrofuran as the mobile phase. The equipment has an autosampler (YL9150), a $5 \mu \mathrm{m}$ column of $300 \times 7.5 \mathrm{~mm}$ (MIXED-C PLgel), and a refractive index detector (YL9170). The analyses were determined under the following conditions: Flow rate of $1.0 \mathrm{~mL} \mathrm{~min}-1$ for $15 \mathrm{~min}$, furnace temperature in the column of $25^{\circ} \mathrm{C}$, and injection volume of $25 \mu \mathrm{L}$. 


\subsection{Infrared Spectroscopy Analysis}

The composite functional groups were identified using an infrared spectrometer (FTIR380, Nicolet, Thermo Fisher, Waltham, MA, USA) using the KBr pellet method, and scan of 4000 to $650 \mathrm{~cm}^{-1}$ with a resolution of $4 \mathrm{~cm}^{-1}$, and 32 scans were performed per sample.

\subsection{Differential Scanning Calorimetry Analysis}

The composite thermal behavior was determined by using a differential scanning calorimeter (DSC 8000, Perkin-Elmer, Waltham, MA, USA). The measurements were carried out with $10 \mathrm{mg}$ of sample, in the range of 20 to $350{ }^{\circ} \mathrm{C}$, at a heating rate of $10^{\circ} \mathrm{C}$ min-1, under nitrogen atmosphere.

\subsection{X-ray Diffraction Analysis}

The room temperature XRD was performed in a powder X-ray diffractometer (EMPYREAN, PANalytical, Malvern, UK) using Cu-K $\alpha 1$ wavelength of $1.5406 \AA, 40 \mathrm{KV}$, and $40 \mathrm{~mA}$. The measurement was made within the 2-theta scale from $5^{\circ}$ to $45^{\circ}$ with a step size of $0.025^{\circ}$.

\subsection{Nuclear Magnetic Resonance Analysis}

The composite structure was also analyzed by proton nuclear magnetic resonance ( $\left.{ }^{1} \mathrm{H}-\mathrm{NMR}\right)$ (600 MHz NMR, Varian, Palo Alto, CA, USA). The measurements were made at room temperature using DMSO-d6 as the solvent.

\subsection{Morphological Analysis}

The morphology was determined in a scanning electron microscope (SEM) model JSM-6510LV brand JEOL (Tokyo, Japan) with an acceleration voltage of $20.0 \mathrm{kV}$ and a spot-size of 60 and working distance of $15 \mathrm{~mm}$. The samples previously were coated with gold/palladium by an electrodeposition method.

\subsection{Determination of Hardness Shore D}

The measured of hardness of the composites with a Shore " $\mathrm{D}$ " durometer PRECISION Shore Model $\mathrm{D}$, was used in cubic specimens of $2 \mathrm{~cm}$ edge material, the measurements were taken at 10 measuring points at each sample, and the mean values and standard deviations were calculated in accordance to ASTM standard D2240.

\subsection{Contact Angle Determination}

The analysis of the hydrophilic nature of the composites, a RameHart Instruments Model 200 contact angle meter (Succasunna, NJ, USA) was used, using deionized water as test fluid, the reported value in this work was the average contact angle of at least three droplets deposited at different positions of the sample surface.

\section{Results and Discussion}

The butyl acrylate (BA) monomer was included to impart slight flexibility and to prevent obtaining a brittle composite [43]. Figure 1 shows the conversion of styrene in composite LEBA15 as a function of time. As noted, after $1.3 \mathrm{~h}$ the residual styrene was less than $0.04 \%$; after this time, the conversion reached a steady state, so the composite synthesis can be stopped. This method of synthesis has advantages over other reports that involve the incorporation of lignin in polymeric matrices, which require the use of solvents or a pre-treatment to lignin $[42,44,45]$ or are necessary longer synthesis time $[29,46]$.

After this time, the conversion reaches a steady state, so the synthesis of the composite can be stopped at $1.5 \mathrm{~h}$ of reaction. Short reaction time implies energy savings when the compound is developed at an industrial level. 


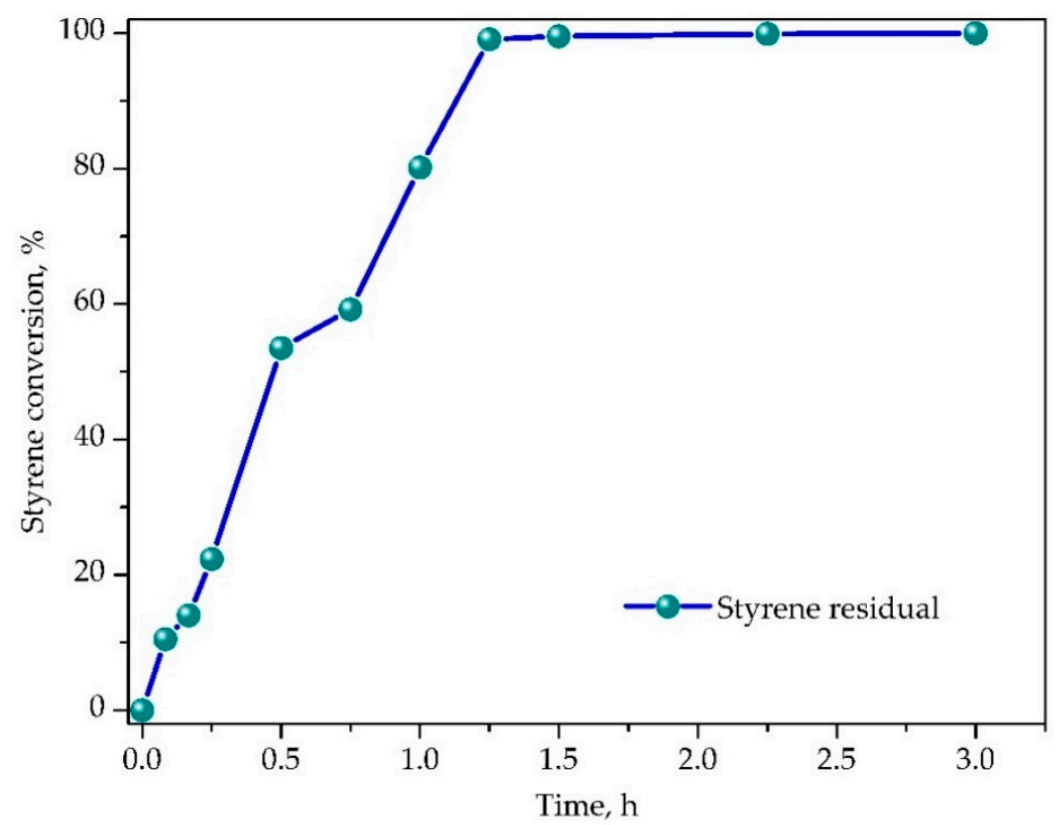

Figure 1. Conversion of styrene versus time in experiment LEBA15.

\subsection{GPC Analysis}

A GPC analysis was performed in the copolymer EBA to determine weight average molar mass $(\mathrm{Mw})$, number average molar mass $(\mathrm{Mn})$ and polydispersity $(\mathrm{I}=\mathrm{Mw} / \mathrm{Mn})$. In this experiment, the synthesis of EBA was realized under nitrogen $\left(\mathrm{N}_{2}\right)$ and air atmospheres to study the influence of the atmosphere in the composite polymerization. The results are reported in Table 2; as observed, the high polydispersity indicates that there was wide molecular weight distribution. In bulk polymerization, the viscosity of the medium increases gradually along the polymerization time; so, the radical propagation is slow, consequently, the termination of the chains occurs faster than the growth, generating high polydispersity [47-49]. A slight increase in the molecular weight and polydispersity was obtained in the copolymer synthesized under $\mathrm{N}_{2}$ [48], which implies that the functionality of the initiator is not seriously affected by the presence of oxygen in the air atmosphere, so it is not necessary to use an inert atmosphere.

Table 2. Gel permeation chromatography (GPC) results for EBA copolymer with air atmosphere and $\mathrm{N}_{2}$.

\begin{tabular}{cccc}
\hline Atmosphere & Mn & Mw & I \\
\hline Air & 15,404 & 83,986 & 5.45 \\
Nitrogen & 18,339 & 87,678 & 4.78 \\
\hline
\end{tabular}

\subsection{FTIR Analysis}

The FTIR spectra of EBA copolymer, lignin, and LEBA15 composite are shown in Figure 2. For EBA, the main signals are observed at $3100 \mathrm{~cm}^{-1}$, corresponding to the stretching vibration of the $\mathrm{C}-\mathrm{H}$ bond in the aromatic ring of styrene monomer unit; at 2934 and $2846 \mathrm{~cm}^{-1}$, assigned to asymmetric and symmetric stretching vibrations, respectively, of the $\mathrm{C}-\mathrm{H}$ bond of the methylene groups of the polymeric backbone. And at $1731 \mathrm{~cm}^{-1}$, the corresponding stretching vibration of the $\mathrm{C}=\mathrm{O}$ group of the acrylate functionality, which appeared very weak due to the small content in the copolymer (14 wt.\%). 


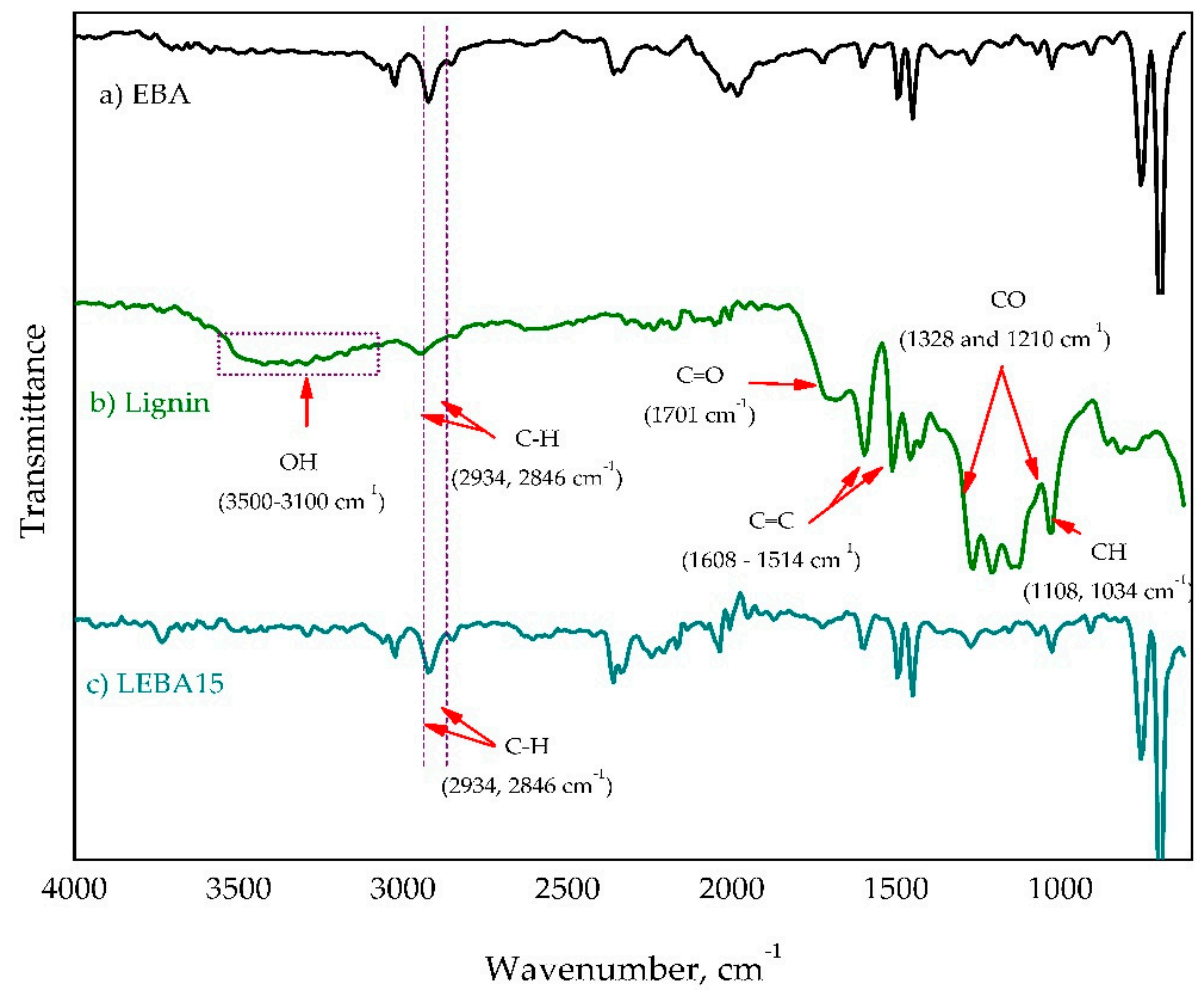

Figure 2. Infrared spectra of (a) EBA, (b) Lignin, and (c) LEBA15.

The spectrum of lignin exhibited the structural complexity of this biopolymer. The wideband between 3500 and $3100 \mathrm{~cm}^{-1}$ was attributed to the stretching vibration of $-\mathrm{OH}$ groups; the bands at 2934 and $2846 \mathrm{~cm}^{-1}$ were associated with the stretching vibrations of $\mathrm{C}-\mathrm{H}$ of methylene group, while the band at $1701 \mathrm{~cm}^{-1}$ was ascribed to the stretching vibration of $\mathrm{C}=\mathrm{O}$ of ester groups. The band at $1608 \mathrm{~cm}^{-1}$ was attributed to the stretching vibration of $\mathrm{C}=\mathrm{C}$ bonds in the aromatic ring [50-52]. Finally, the signals between 828 and $614 \mathrm{~cm}^{-1}$, are due to deformations outside the plane of the aromatic $\mathrm{CH}$ bonds, similar to reported by other authors [50,53].

In the spectra for LEBA15, the band corresponding of the -OH groups from the lignin not be solved, the intensity decreases because these groups probably react with short chains of monomers, causing the formation of the composite. The formation of bonds in the alcoholic and phenolic groups of lignin has already been reported by Dick et al. [54] in their work about chemical modification and grafting induced by lignin plasma in polyacid lactic acid. In this sense, Fuxiang et al., in various research works, shows that the decrease in the intensity of the band of -OH groups of lignin is the main mechanism of interaction for the incorporation of this with the polymer matrix of interest $[29,55]$; in this same sense, in this research, a decrease in the intensity of band of the -OH groups of lignin was observed and it is associated with its possible interaction with the acrylate groups of the copolymer (Scheme 1) for the formation of the composites, which is demonstrated by the decrease in the intensity of the band between $1740-1710 \mathrm{~cm}^{-1}$ typical of the acrylate for the LEBA15 composite (Figure 3). 


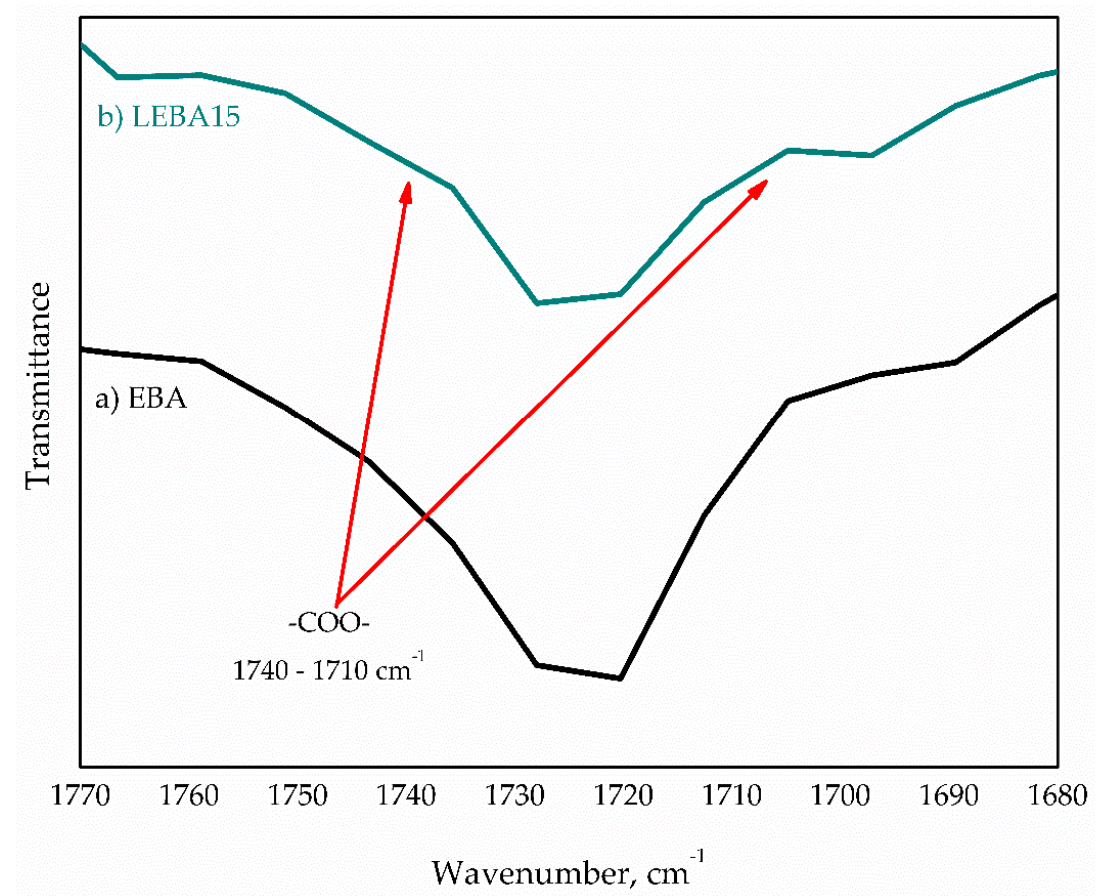

Figure 3. Infrared spectra of (a) EBA and (b) LEBA15.

\subsection{DSC Analysis}

The lignin, copolymer EBA, and LEBA composites were characterized by DSC to determine the glass transition temperature $\left(T_{\mathrm{g}}\right)$ (Figure 4 ). As seen, the $T_{\mathrm{g}}$ of the composites was slightly lower than the $T_{\mathrm{g}}$ of the pure copolymer and there seems to be no trend with respect to the lignin content. It is believed that the presence of lignin into the copolymer affected the mobility of the polymer chains [56,57], due to the intermolecular hydrogen bond between hydroxyl functional groups of lignin and the carbonyl groups of the copolymer [58].

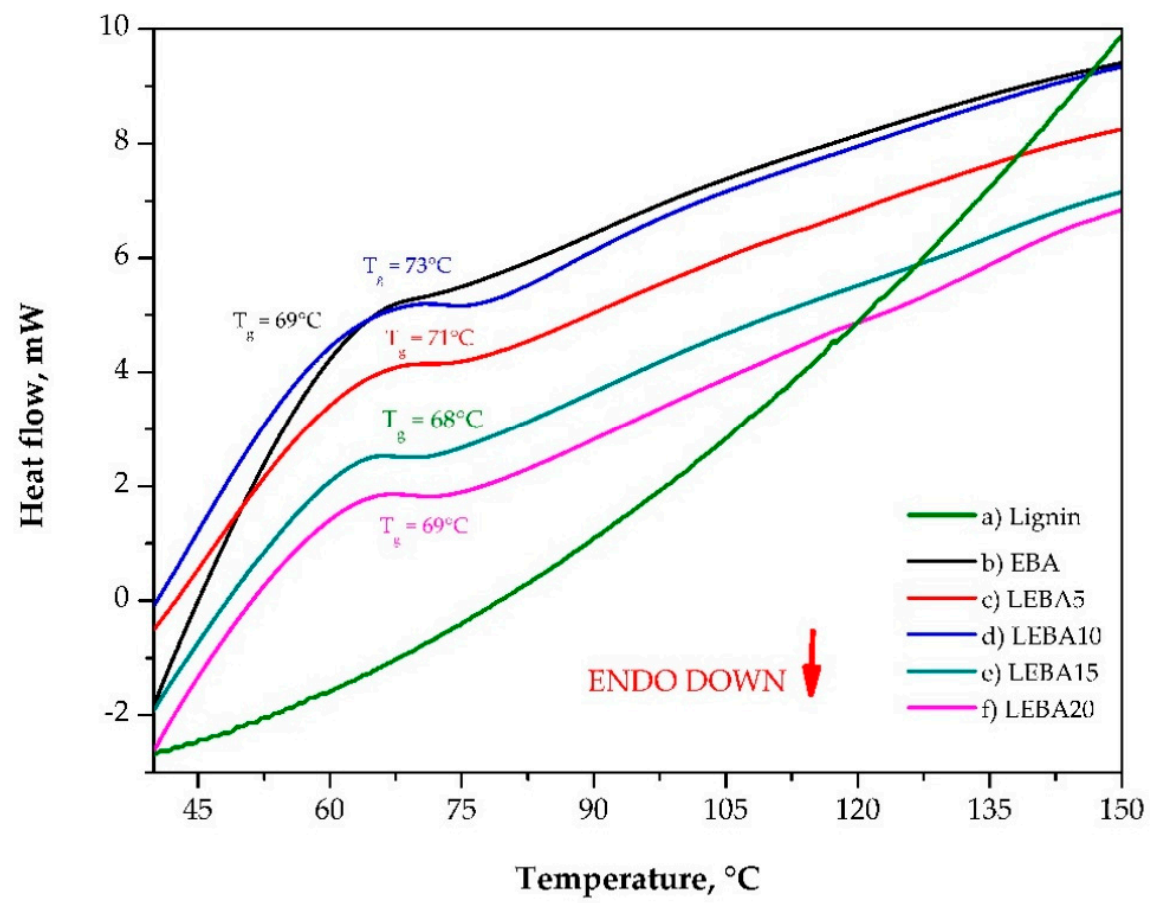

Figure 4. Differential scanning calorimeter (DSC) curves for (a) Lignin, (b) EBA, (c) LEBA5, (d) LEBA10, (e) LEBA15 and (f) LEBA20 composites. 
However, in the composites LEBA15 and LEBA20 the relationship between S and BA was increased, causing the polymeric chains of these composites to be a little more flexible due to the increase in the BA [59].

\subsection{X-ray Diffraction Anlysis}

Figure 5 shows the diffraction patterns for the composites, is observed that lignin and EBA did not exhibit any signal of sharp diffraction peaks, indicated that are amorphous materials. At low amount of lignin, the amorphous phase of the composite prevails. However, increasing the amount of lignin appeared peak at $26^{\circ}$ on 2 theta for LEBA10 to LEBA20 on the XRD diffraction, because the interaction sites between the lignin and the copolymer are increased, this causes increased probability that the chains fit between gaps of lignin, which makes some structures form ordered aggregation.

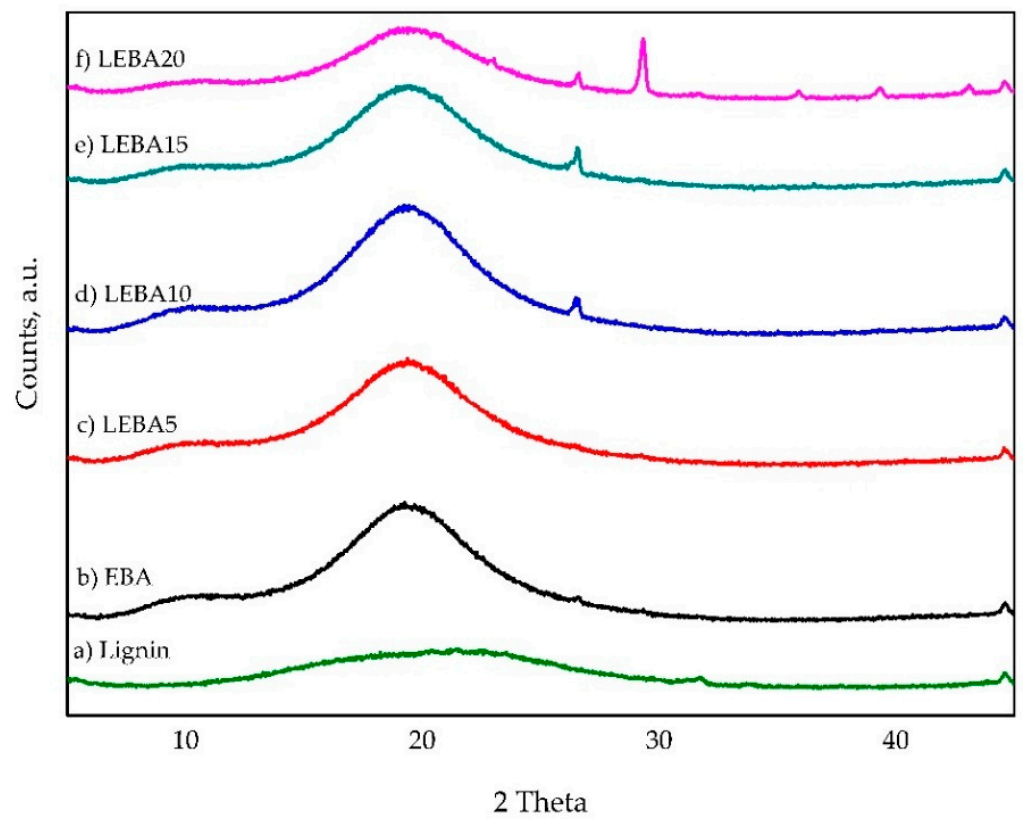

Figure 5. X-ray diffraction patterns for the samples: (a) Lignin, (b) EBA, (c) LEBA5, (d) LEBA10, (e) LEBA15, and (f) LEBA20.

However, the composite LEBA20 showed diffraction peaks at higher values of 2 theta, several authors which have already reported this kind of diffractograms to attribute the origin of this additional peak to a scattering signal related to the lateral groups of the same size and almost regularly spaced, this agrees with the fact that LEBA20 has the highest BA/St ratio [60], the main amorphous signal located around $20^{\circ}$ results from the contribution of both the lignin and the copolymer chains, the disappearance or decrease in intensity of this signals for the intermediate BA/St ratio indicates a loss of this characteristic length, which may suggest that the grafted chains are rather composed of random copolymers.

\section{5. ${ }^{1} \mathrm{H}-\mathrm{NMR}$ Analysis}

By means of the ${ }^{1} \mathrm{H}$ NMR characterization of the LEBA $15 \%$ composite, a direct comparison was achieved with the ${ }^{1} \mathrm{H}$ NMR spectrum of Lignin, where we were able to assign different characteristic signals of the material (Figure 6). 

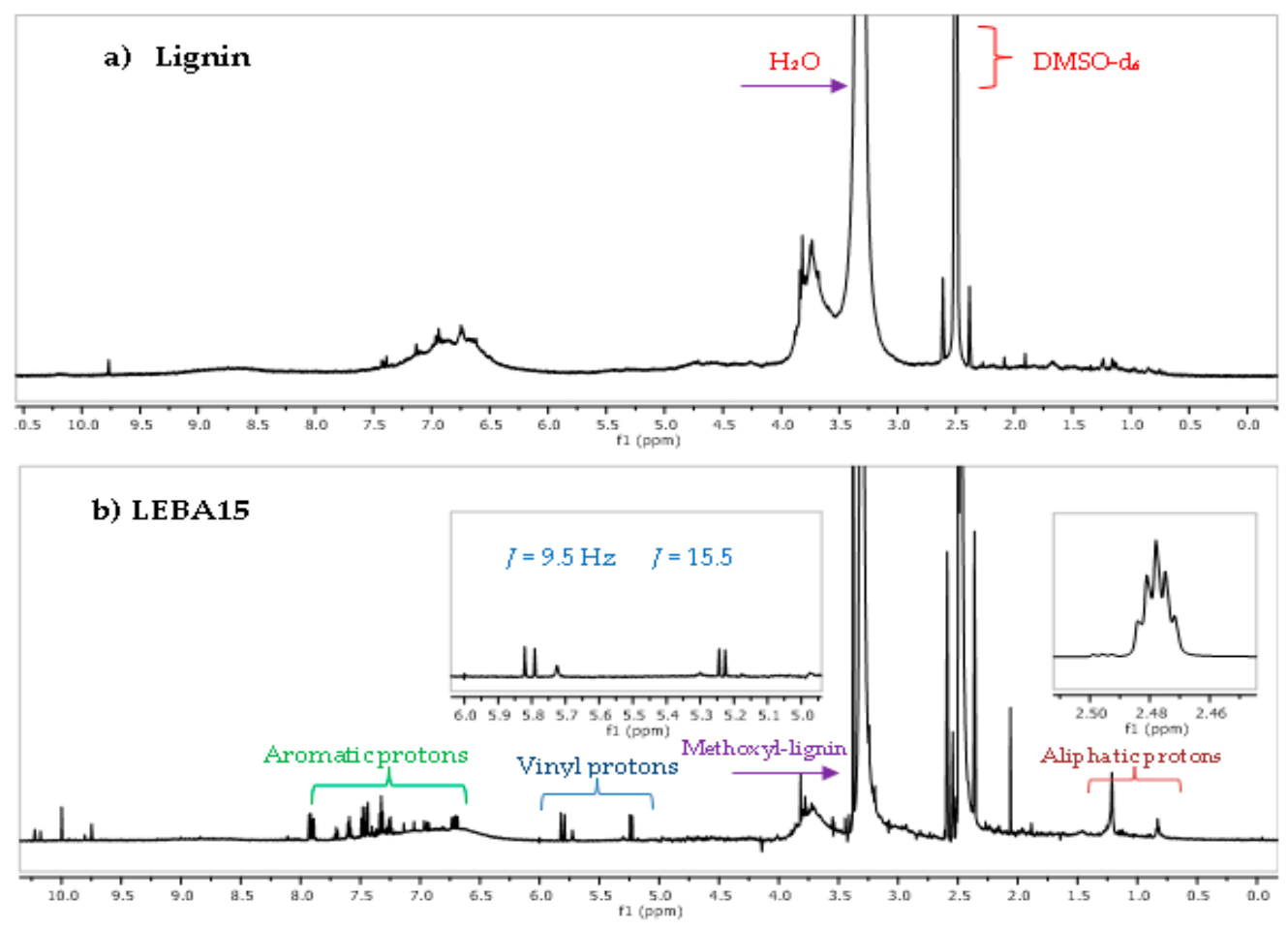

Figure 6. ${ }^{1} \mathrm{H}-\mathrm{NMR}$ spectra (DMSO-d $\mathrm{d}_{6}, 25^{\circ} \mathrm{C}, 400 \mathrm{MHz}$ ) for: (a) Lignin and (b) LEBA15.

Due to their complex structure, lignins present equally complex spectra; however, they maintain a characteristic pattern. The most common functional groups present in lignins are the methoxy group $\left(\mathrm{Ar}-\mathrm{O}-\mathrm{CH}_{3}\right)$, various types of ethers ( $\left.\mathrm{R}-\mathrm{O}-\mathrm{R}, \mathrm{Ar}-\mathrm{O}-\mathrm{R}, \mathrm{Ar}-\mathrm{O}-\mathrm{Ar}\right)$, aldehydes $(\mathrm{R}-\mathrm{H}-\mathrm{C}=\mathrm{O})$, phenols $(\mathrm{Ar}-\mathrm{OH})$ and aliphatic alcohols $(\mathrm{R}-\mathrm{OH})$, among several others. Figure 5 shows the spectrum of the LEBA15 composite. Two signals appear in the spectrum, one in $2.4 \mathrm{ppm}$ and another in $3.35 \mathrm{ppm}$, the first corresponds to the DMSO signal used as the solvent and the second to the trace of water contained in the DMSO. In the area close to $10 \mathrm{ppm}$, a small group of signals is observed, which has been related to protons in benzaldehyde groups [61]; a more prominent set of signals between 6 and 9 ppm was attributed to protons of aromatic OH groups in syringyl (S) and guaiacyl (G) units; at 3.75 ppm appears a multiplet attached to the protons of methoxy groups related to $S$ and $G$ units; the signals between 0.6 and $1.25 \mathrm{ppm}$ correspond to the protons of the aliphatic groups. Two doublets are also observed at 5.25 and $5.8 \mathrm{ppm}$, which are characteristic of protons in unsaturated groups $(\mathrm{C}=\mathrm{C})$. Unlike Lignin, which does not have double bonds in its structure. Once it is coupled with styrene and butyl acrylate, it can be observed in $5.25 \mathrm{ppm}$ a doublet with a coupling constant of $J=15.5 \mathrm{~Hz}$, in 5.80 another doublet with a coupling constant of $J=9.5 \mathrm{~Hz}$ which means the presence of two isomers of configuration (E) and (Z), this may be due to the conformational arrangement of the functional groups that lignin presents within its macrocyclic polymer structure. On this type of signals, the literature indicates that they usually occur in arrangements of type $\beta-\mathrm{O}-4$ [62], remnants of the biopolymerization of monolignols [63].

This set of signals is in agreement with spectra reported in the literature for lignins [61]. With respect to the copolymer, the signals of the repeating units of styrene and butyl acrylate appear to be masked by those of lignin since in most cases the protons are coincident. However, we can mention the multiplet (two double of doubles) at $6.75 \mathrm{ppm}$ observed in polystyrenes and the set of signals between 7.25 and $7.5 \mathrm{ppm}$ attributed to the aromatic ring protons; however, aromatic groups in lignin also occur in this area. As for the repeating units of butyl acrylate, they are not clearly observed, probably due to the low content of this monomer in the composite. 


\subsection{Morphological Analysis}

Figure 7 portrays the morphology for lignin, LEBA5, LEBA15, and LEBA20. The image of the pure lignin (a) showed an irregular distribution of particles in the form of spheres of size varying from 30 to $150 \mu \mathrm{m}$.
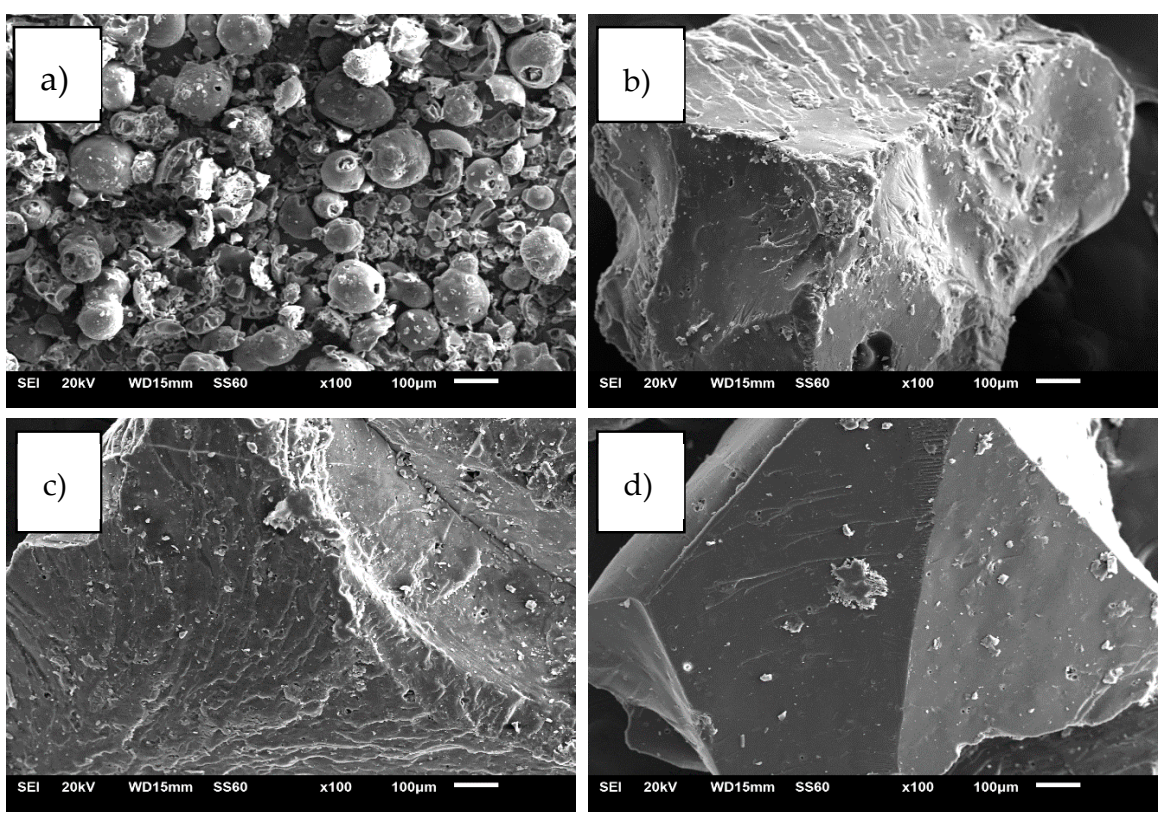

Figure 7. SEM micrographs for samples of (a) lignin, (b) LEBA5, (c) LEBA15, and (d) LEBA20.

With the increase of the lignin, the composite surface became smoother (Figure $6 \mathrm{~b}, \mathrm{c}, \mathrm{d}$ ), suggesting that there was a link between the functional groups of lignin and the copolymer. Similar behavior was reported by Yang et al., they report the preparation of lignin pristine (LP) reinforced polymethyl methacrylate (PMMA) composites, obtained by combining solvent-free radical polymerization, obtaining making the particles totally embedding into the PMMA chain and can be ascribed to excellent bonding effect of LP whit PMMA, this represents increment in the mechanical properties of composites, by not presenting empty spaces between the lignin and the polymeric matrix [64].

\subsection{Determination of Hardness}

Specimens were prepared from the composites in order to evaluate hardness Shore D, according to ASTM D 2240, the measurements were made by triplicate. As illustrated in Figure 8, the results indicated that the composites with 5 and $10 \mathrm{wt} . \%$ lignin had lower hardness than the pure copolymer EBA. However, for the composites with higher contents of lignin an increasing in hardness was observed. Yang et al. present the Shore D hardness values of PMMA material sheets incorporating various contents of LP, with the increase of LP loading from 0 to $4.5 \mathrm{wt} . \%$, the Shore D hardness rise from 75.0 to 79.0 [64]. 


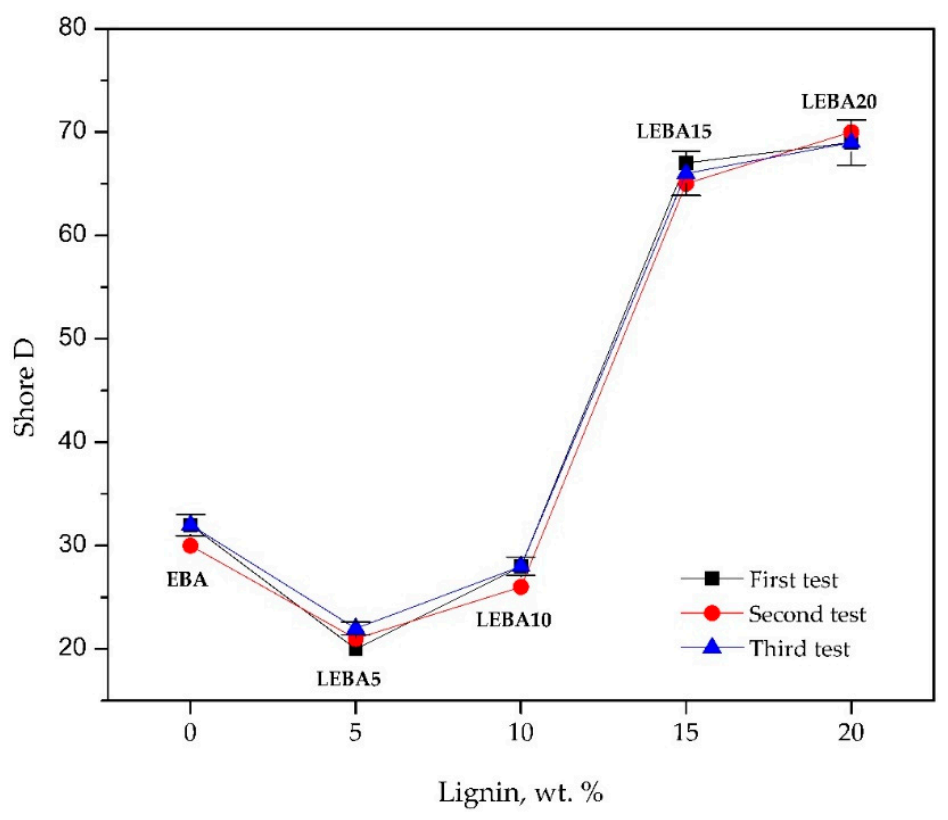

Figure 8. Shore D hardness vs. lignin wt. $\%$.

These results are agreement with the SEM images and DSC supporting the hypothesis that lignin is embedded within the polymer chains forming a material with smooth surface, the incorporation of this biopolymer favored the mechanical properties of LEBA composites, opening the possibility of the application of this material; for example, in the removal of hydrocarbons from water since for this application [43].

\subsection{Contact Angle}

Figure 9 shows the results of the determination of the contact angle for the EBA copolymer and the LEBA composites.

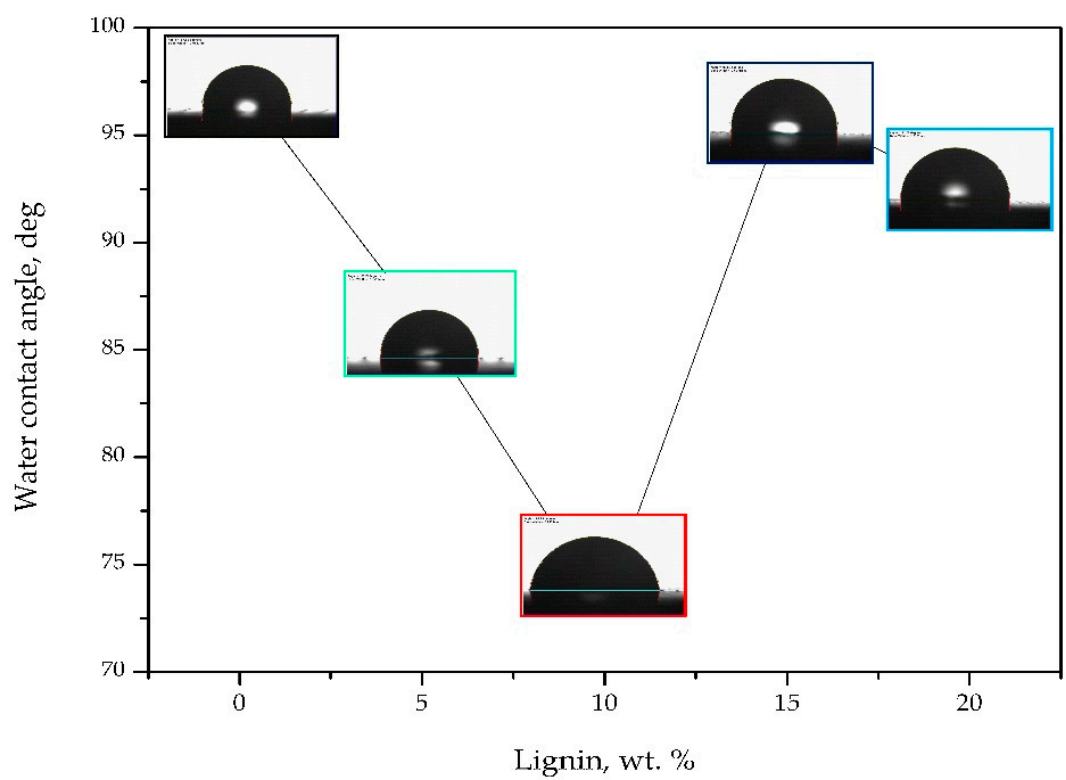

Figure 9. Water contact angle vs. lignin wt.\%.

The contact angle for EBA $\left(97.5^{\circ}\right)$ showed a hydrophobic nature that agrees with that reported in the literature for polymeric materials based on styrene $[65,66]$; On the other hand, the composites LEBA5 and LEBA10 showed a more hydrophilic character that could be associated with the presence 
of lignin due to its hydrophilic nature [65]. In contrast, for LEBA15 and LEBA20 the hydrophobic character was accentuated, despite containing higher loads of lignin. This behavior can be attributed to a higher $\mathrm{BA} /$ styrene ratio [67]. According to this, the interaction of $-\mathrm{OH}$ groups of lignin with the copolymer during free radical polymerization increased (Scheme 2), occupying a higher proportion of this groups, which caused the decrement in the hydrophilic character associated with lignin [65].

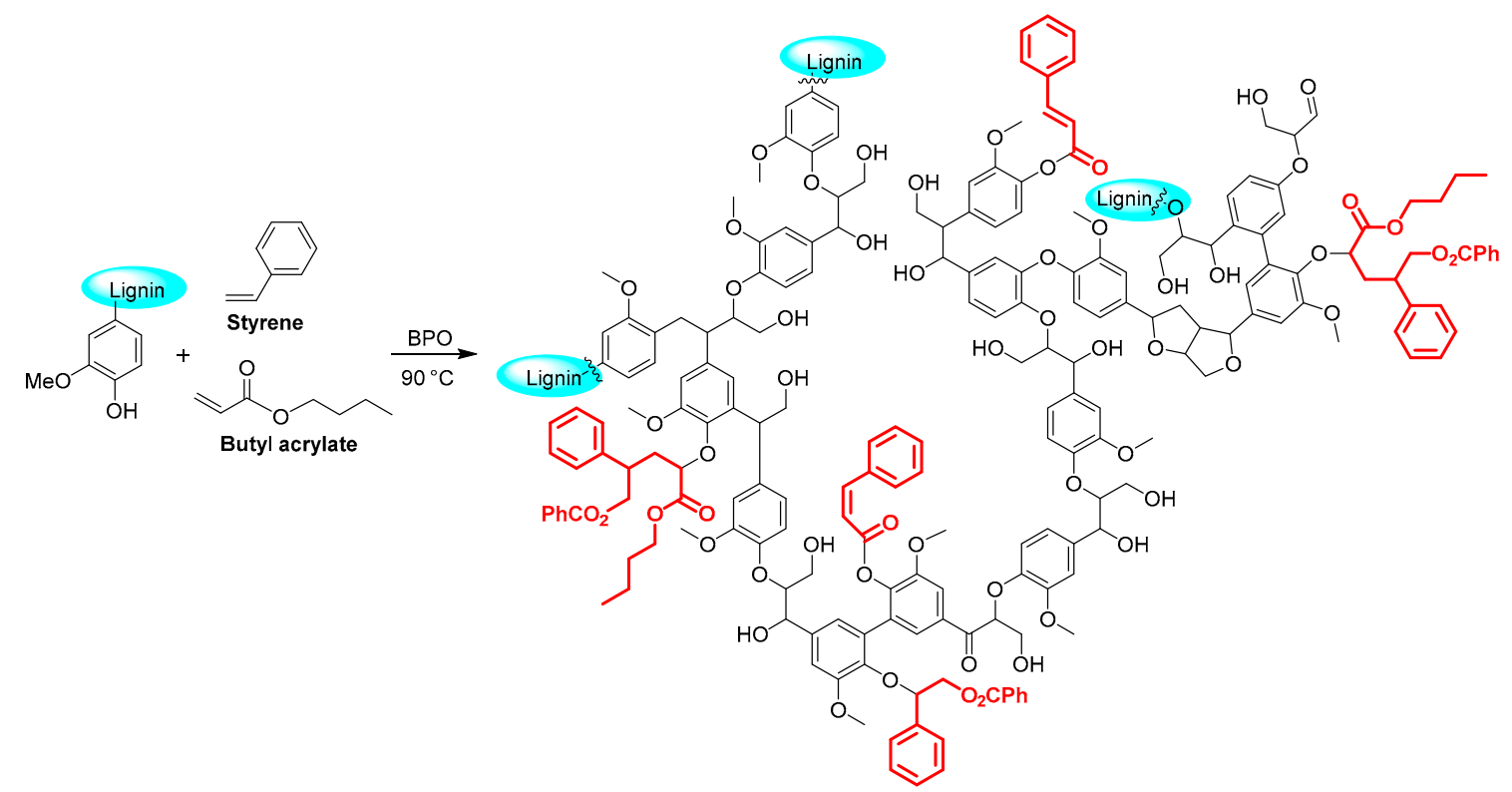

Scheme 2. Schematic diagram of the probable links in composites synthetized with lignin and styrene-butyl acrylate.

In this sense, some research in the synthesis of lignin-based materials, reported that the increase of lignin in the polymer matrix influences the increment of the hydrophilic character (Table 3), because lignin acts as a filler [68]. On the other hand, under the synthesis conditions proposed in this research it was shown that the increase in the amount of lignin (LEBA15 and LEBA20) had no significant effect on the hydrophobic character of the styrene-butyl acrylate system.

Table 3. Effect of lignin in water contact angle for different polymer matrices.

\begin{tabular}{|c|c|c|c|}
\hline Polymer & Type lignin & Application & Water Contact Angle, $^{\circ}$ \\
\hline Polyurethane (PU) [68] & $\begin{array}{l}\text { Lignin waste (5.0 to } \\
20.0 \mathrm{wt} . \%)\end{array}$ & Removal oil in water & $\begin{array}{l}123.0^{\circ} \text { for PU to } 90.0^{\circ} \text { for PU } \\
\text { whit } 20 \mathrm{wt} . \% \text { of lignin }\end{array}$ \\
\hline Polypropylene (PP) [69] & Kraft lignin acid (5.0 wt.\%) & Adhesion properties & $\begin{array}{l}\text { 107. } 2^{\circ} \text { for PP and } 92.46^{\circ} \text { for PP } \\
\text { whit Kraft lignin (acid) }\end{array}$ \\
\hline Polystyrene (PS) [70] & $\begin{array}{l}\text { Alkali lignin }(6.5 \mathrm{wt} . \%) \\
\text { modified whit trimethyl } \\
\text { quaternary ammonium salt }\end{array}$ & Antibacterial activity & $\begin{array}{l}55.9^{\circ} \text { for PS and } 10.5^{\circ} \text { for PS } \\
\text { whit lignin }\end{array}$ \\
\hline
\end{tabular}

\section{Conclusions}

A novel composite was synthetized with lignin and styrene-butyl acrylate copolymer. Under the conditions of the composite formation, the results indicated that the-OH groups of lignin were the main site of bonding with the copolymer chains, this was evidenced by the reduction of the hydroxyl groups signals in infrared spectroscopy. Gel permeation chromatography showed that the atmosphere of nitrogen in the reaction medium did not contribute significantly to the inhibition of the free radicals during copolymerization. In addition, electron microscopy showed that the lignin was incorporated with the copolymer, losing its granular morphology and producing a smooth surface, which was related to FTIR observations. Respecting surface characterization, it was found that lignin loading 
modified the composites hardness and the hydrophilic-lipophilic character. The more hydrophobic character of LEBA15 and LEBA20 composites supported the assumption of the chemical interaction between the $\mathrm{OH}$ groups of lignin and the copolymer chains during free radical polymerization.

According to the properties observed, it is possible to suggest applications for the composites; for example, based on the lipophilic nature, the composites could be used as adsorbent materials for the removal of hydrocarbon spills from water.

Author Contributions: Conceptualization, (D.L.S.), (A.A.Z.C.), (E.A.Z.C.) and (M.G.S.A.); Data curation, (D.L.S.), (M.A.R.G.) and (M.G.S.A.); Formal analysis, (D.L.S.) and (M.G.S.A.); Investigation, (D.L.S.) and (M.G.S.A.); Methodology, (D.L.S.), (M.A.R.G.), (A.A.Z.C.), (E.A.Z.C.) and (M.G.S.A.); Project administration, (M.G.S.A.); Supervision, (P.E.M.), (A.A.Z.C.), (E.A.Z.C.) and (M.G.S.A.); Validation, (P.E.M.); Visualization, (P.E.M.) and (M.G.S.A.); Writing - original draft, (D.L.S.) and (M.G.S.A.); Writing - review \& editing, (D.L.S.) and (M.G.S.A.).

Funding: This research received no external funding.

Acknowledgments: The authors wish to the National Council for Science and Technology of Mexico (CONACYT) for the scholarship awarded to Daniel López Serna (Scholarship 485479). We also wish to thank Claudia A. Hernández-Escobar for the support in technical analysis.

Conflicts of Interest: The authors declare no conflict of interest.

\section{References}

1. Le Digabel, F.; Avérous, L. Effects of lignin content on the properties of lignocellulose-based biocomposites. Carbohydr. Polym. 2006, 66, 537-545. [CrossRef]

2. Nanou, P.; Huijgen, W.J.J.; Carbo, M.C.; Kiel, J.H.A. The role of lignin in the densification of torrefied wood in relation to the final product properties. Biomass Bioenergy 2018, 111, 248-262. [CrossRef]

3. Li, Z.; Zhong, L.; Zhang, T.; Qiu, F.; Yue, X.; Yang, D. Sustainable, Flexible, and Superhydrophobic Functionalized Cellulose Aerogel for Selective and Versatile Oil/Water Separation. ACS Sustain. Chem. Eng. 2019, 7, 9984-9994. [CrossRef]

4. Wood, B.M.; Coles, S.R.; Maggs, S.; Meredith, J.; Kirwan, K. Use of lignin as a compatibiliser in hemp/epoxy composites. Compos. Sci. Technol. 2011, 71, 1804-1810. [CrossRef]

5. Menon, M.P.; Selvakumar, R.; Suresh kumar, P.; Ramakrishna, S. Extraction and modification of cellulose nanofibers derived from biomass for environmental application. R. Soc. Chem. 2017, 7, 42750-42773.

6. Feng, Y.; Lan, J.; Ma, P.; Dong, X.; Qu, J.; He, H. Chemical structure and thermal properties of lignin modified with polyethylene glycol during steam explosion. Wood Sci. Technol. 2016, 51, 135-150. [CrossRef]

7. Luo, S.; Cao, J.; Mcdonald, A.G. Esterification of industrial lignin and its effect on the resulting poly(3-hydroxybutyrate-co-3-hydroxyvalerate) or polypropylene blends. Ind. Crop. Prod. 2017, 97, 281-291. [CrossRef]

8. Stewart, D. Lignin as a base material for materials applications: Chemistry, application and economics. Ind. Crops Prod. 2008, 27, 202-207. [CrossRef]

9. Xie, S.; Li, Q.; Karki, P.; Zhou, F.; Yuan, J.S. Lignin as Renewable and Superior Asphalt Binder Modifier. ACS Sustain. Chem. Eng. 2017, 5, 2817-2823. [CrossRef]

10. Iyer, K.A.; Torkelson, J.M. Sustainable Green Hybrids of Polyolefins and Lignin Yield Major Improvements in Mechanical Properties When Prepared via Solid-State Shear Pulverization. ACS Sustain. Chem. Eng. 2015, 3, 959-968. [CrossRef]

11. Saito, T.; Brown, R.H.; Hunt, M.A.; Pickel, D.L.; Pickel, J.M.; Messman, J.M.; Baker, F.S.; Keller, M.; Naskar, A.K. Turning renewable resources into value-added polymer: Development of lignin-based thermoplastic. Green Chem. 2012, 14, 3295. [CrossRef]

12. Şimşek, S.; Ulusoy, H.İ. Synthesis of a Useful and Economic Polymeric Material for Effective Removal of Bisphenol A. J. Polym. Environ. 2018, 26, 1605-1612. [CrossRef]

13. Bilal, M.; Asgher, M.; Iqbal, H.M.N.; Hu, H.; Zhang, X. Biotransformation of lignocellulosic materials into value-added products-A review. Int. J. Biol. Macromol. 2017, 98, 447-458. [CrossRef] [PubMed]

14. Li, Y.; Yang, D.; Lu, S.; Qiu, X.; Qian, Y.; Li, P. Encapsulating $\mathrm{TiO}_{2}$ in Lignin-Based Colloidal Spheres for High Sunscreen Performance and Weak Photocatalytic Activity. ACS Sustain. Chem. Eng. 2019, 7, 6234-6242. [CrossRef] 
15. Fernández-Rodríguez, J.; Erdocia, X.; Sánchez, C.; González Alriols, M.; Labidi, J. Lignin depolymerization for phenolic monomers production by sustainable processes. J. Energy Chem. 2017, 26, 622-631. [CrossRef]

16. Park, S.; Hong, C.; Jeong, H.; Lee, S.; Weon, J.; Choi, I.; Kashif, M.; Sarkar, B.; Zeb, H.; Yi, M.; et al. Progress in Green Polymer Composites from Lignin for Multifunctional Applications: A Review. J. Environ. Radioact. 2017, 121, 47-56.

17. Chung, Y.L.; Olsson, J.V.; Li, R.J.; Frank, C.W.; Waymouth, R.M.; Billington, S.L.; Sattely, E.S. A renewable lignin-lactide copolymer and application in biobased composites. ACS Sustain. Chem. Eng. 2013, 1, 1231-1238. [CrossRef]

18. Tran, C.D.; Chen, J.; Keum, J.K.; Naskar, A.K. A New Class of Renewable Thermoplastics with Extraordinary Performance from Nanostructured Lignin-Elastomers. Adv. Funct. Mater. 2016, 26, 2677-2685. [CrossRef]

19. Wang, Z.; Yuan, L.; Tang, C. Sustainable Elastomers from Renewable Biomass. Acc. Chem. Res. 2017, 50, 1762-1773. [CrossRef]

20. Jairam, S.; Tong, Z.; Wang, L.; Welt, B. Encapsulation of a biobased lignin-saponite nanohybrid into polystyrene co-butyl acrylate (PSBA) latex via miniemulsion polymerization. ACS Sustain. Chem. Eng. 2013, 1, 1630-1637. [CrossRef]

21. Wei, Z.; Yang, Y.; Yang, R.; Wang, C. Alkaline lignin extracted from furfural residues for pH-responsive Pickering emulsions and their recyclable polymerization. Green Chem. 2012, 14, 3230-3236. [CrossRef]

22. Naseem, A.; Tabasum, S.; Zia, K.M.; Zuber, M.; Ali, M.; Noreen, A. Lignin-derivatives based polymers, blends and composites: A review. Int. J. Biol. Macromol. 2016, 93, 296-313. [CrossRef] [PubMed]

23. Pan, Y.; Peng, C.; Wang, W.; Shi, K.; Liu, Z.; Ji, X. Preparation and absorption behavior to organic pollutants of macroporous hydrophobic polyvinyl alcohol-formaldehyde sponges. RSC Adv. 2014, 4, 35620-35628. [CrossRef]

24. Wang, Y.; Xiong, Y.; Wang, J.; Zhang, X. Ultrasonic-assisted fabrication of montmorillonite-lignin hybrid hydrogel: Highly efficient swelling behaviors and super-sorbent for dye removal from wastewater. Colloids Surf. A Phys. Eng. Asp. 2017, 520, 903-913. [CrossRef]

25. Feldman, D. Lignin nanocomposites. J. Macromol. Sci. Part A Pure Appl. Chem. 2016, 53, 382-387. [CrossRef]

26. Espinoza Acosta, J.L.; Torres Chávez, P.I.; Olmedo Martínez, J.L.; Vega Rios, A.; Flores Gallardo, S.; Zaragoza Contreras, E.A. Lignin in storage and renewable energy applications: A review. J. Energy Chem. 2018, 27, 1422-1438. [CrossRef]

27. Ye, D.; Jiang, L.; Ma, C.; Zhang, M.; Zhang, X. The graft polymers from different species of lignin and acrylic acid: Synthesis and mechanism study. Int. J. Biol. Macromol. 2014, 63, 43-48. [CrossRef]

28. Campos, C.H.; Urbano, B.F.; Rivas, B.L. Synthesis and characterization of organic-inorganic hybrid composites from poly(acrylic acid)-[3-(trimethoxysilyl)propyl methacrylate]- $\mathrm{Al}_{2} \mathrm{O}_{3}$. Compos. Part B Eng. 2014, 57, 1-7. [CrossRef]

29. Liu, X.; Xu, Y.; Yu, J.; Li, S.; Wang, J.; Wang, C.; Chu, F. Integration of lignin and acrylic monomers towards grafted copolymers by free radical polymerization. Int. J. Biol. Macromol. 2014, 67, 483-489. [CrossRef]

30. Ferdosian, F.; Yuan, Z.; Anderson, M.; Xu, C. (Charles) Synthesis and characterization of hydrolysis lignin-based epoxy resins. Ind. Crop. Prod. 2016, 91, 295-301. [CrossRef]

31. Nair, S.S.; Kuo, P.; Chen, H.; Yan, N. Investigating the effect of lignin on the mechanical, thermal, and barrier properties of cellulose nanofibril reinforced epoxy composite. Ind. Crop. Prod. 2017, 100, 208-217. [CrossRef]

32. Yeo, J.S.; Lee, J.H.; Hwang, S.H. Effects of lignin on the volume shrinkage and mechanical properties of a styrene/unsaturated polyester/lignin ternary composite system. Compos. Part B Eng. 2017, 130, 167-173. [CrossRef]

33. Gregorova, A.; Kosikova, B.; Osvald, A. The study of lignin influence on properties of polypropylene composites. Wood Res. 2005, 50, 41-48.

34. Kadla, J.F.; Kubo, S.; Venditti, R.A.; Gilbert, R.D.; Compere, A.L.; Griffith, W. Lignin-based carbon fibers for composite fiber applications. Carbon 2002, 40, 2913-2920. [CrossRef]

35. Liu, Y.; Ma, J.; Wu, T.; Wang, X.; Huang, G.; Liu, Y.; Qiu, H.; Li, Y.; Wang, W.; Gao, J. Cost-Effective Reduced Graphene Oxide-Coated Polyurethane Sponge As a Highly Efficient and Reusable Oil-Absorbent. ACS Appl. Mater. Interfaces 2013, 5, 10018-10026. [CrossRef] [PubMed]

36. Chaochanchaikul, K.; Jayaraman, K.; Rosarpitak, V.; Sombatsompop, N. Influence of lignin content on photodegradation in wood/HDPE composites under UV weathering. BioResources 2012, 7, 38-55. 
37. Graichen, F.H.M.; Grigsby, W.J.; Hill, S.J.; Raymond, L.G.; Sanglard, M.; Smith, D.A.; Thorlby, G.J.; Torr, K.M.; Warnes, J.M. Yes, we can make money out of lignin and other bio-based resources. Ind. Crops Prod. 2017, 106, 74-85. [CrossRef]

38. Nordström, Y.; Norberg, I.; Sjöholm, E.; Drougge, R. A new softening agent for melt spinning of softwood kraft lignin. J. Appl. Polym. Sci. 2013, 129, 1274-1279. [CrossRef]

39. Marklund, E.; Eitzenberger, J.; Varna, J. Nonlinear viscoelastic viscoplastic material model including stiffness degradation for hemp/lignin composites. Compos. Sci. Technol. 2008, 68, 2156-2162. [CrossRef]

40. Yeo, J.S.; Seong, D.W.; Hwang, S.H. Chemical surface modification of lignin particle and its application as filler in the polypropylene composites. J. Ind. Eng. Chem. 2015, 31, 80-85. [CrossRef]

41. Sen, S.; Patil, S.; Argyropoulos, D.S. Thermal properties of lignin in copolymers, blends, and composites: A review. Green Chem. 2015, 17, 4862-4887. [CrossRef]

42. Darestani, N.G.; Tikka, A.; Fatehi, P. Sulfonated lignin-g-styrene polymer: Production and characterization. Polymers 2018, 10, 928. [CrossRef] [PubMed]

43. Xu, N.; Cao, J.; Lu, Y. The electrospinning of the copolymer of styrene and butyl acrylate for its application as oil absorbent. Springerplus 2016, 5, 1383. [CrossRef] [PubMed]

44. Konduri, M.K.; Kong, F.; Fatehi, P. Production of carboxymethylated lignin and its application as a dispersant. Eur. Polym. J. 2015, 70, 371-383. [CrossRef]

45. Victor, P.A.; Gonçalves, S.B.; Machado, F. Styrene/Lignin-Based Polymeric Composites Obtained Through a Sequential Mass-Suspension Polymerization Process. J. Polym. Environ. 2017, 26, 1-20. [CrossRef]

46. Han, Y.; Yuan, L.; Li, G.; Huang, L.; Qin, T.; Chu, F.; Tang, C. Renewable polymers from lignin via copper-free thermal click chemistry. Polymer 2016, 83, 92-100. [CrossRef]

47. Nesvadba, P. Radical Polymerization in Industry. Encycl. Radic. Chem. Biol. Mater. 2012, 36. [CrossRef]

48. Cheah, P.; Bhikha, C.N.; Haver, J.H.O.; Smith, A.E. Effect of Oxygen and Initiator Solubility on Admicellar Polymerization of Styrene on Silica Surfaces. Int. J. Polym. Sci. 2017, 2017, 1-7. [CrossRef]

49. Georges, M.K.; Veregin, R.P.N.; Kazmaier, P.M.; Hamer, G.K. Narrow Polydispersity Polystyrene by a Free-Radical Polymerization Process-Rate Enhancement. Macromolecules 1994, 27, 7228-7229. [CrossRef]

50. Upton, B.M.; Kasko, A.M. Strategies for the conversion of lignin to high-value polymeric materials: Review and perspective. Chem. Rev. 2016, 116, 2275-2306. [CrossRef]

51. Derkacheva, O.; Sukhov, D. Investigation of lignins by FTIR spectroscopy. Macromol. Symp. 2008, 265, 61-68. [CrossRef]

52. Zhang, J.; Lin, X.; Luo, X.; Zhang, C.; Zhu, H. A modified lignin adsorbent for the removal of 2,4,6-trinitrotoluene. Chem. Eng. J. 2011, 168, 1055-1063. [CrossRef]

53. Jairam, S.; Bucklin, R.; Correll, M.; Sakthivel, T.S.; Seal, S.; Truett, J.; Tong, Z. UV resistance of polystyrene co-butyl acrylate (PSBA) encapsulated lignin-saponite nanohybrid composite film. Mater. Des. 2016, 90, 151-156. [CrossRef]

54. Atz Dick, T.; Couve, J.; Gimello, O.; Mas, A.; Robin, J.J. Chemical modification and plasma-induced grafting of pyrolitic lignin. Evaluation of the reinforcing effect on lignin/poly(L-lactide) composites. Polymer 2017, 118, 280-296. [CrossRef]

55. Liu, X.; Wang, J.; Yu, J.; Zhang, M.; Wang, C.; Xu, Y.; Chu, F. Preparation and characterization of lignin based macromonomer and its copolymers with butyl methacrylate. Int. J. Biol. Macromol. 2013, 60, 309-315. [CrossRef] [PubMed]

56. Sahoo, S.; Misra, M.; Mohanty, A.K. Enhanced properties of lignin-based biodegradable polymer composites using injection moulding process. Compos. Part A Appl. Sci. Manuf. 2011, 42, 1710-1718. [CrossRef]

57. Gordobil, O.; Egüés, I.; Llano-Ponte, R.; Labidi, J. Physicochemical properties of PLA lignin blends. Polym. Degrad. Stab. 2014, 108, 330-338. [CrossRef]

58. Ayoub, A.; Venditti, R.A.; Jameel, H.; Chang, H.M. Effect of irradiation on the composition and thermal properties of softwood kraft lignin and styrene grafted lignin. J. Appl. Polym. Sci. 2014, 131, 1-10. [CrossRef]

59. Ning, L.Q.; Xu, N.K.; Wang, R.; Liu, Y. Fibrous membranes electrospun from the suspension polymerization product of styrene and butyl acrylate for oil-water separation. RSC. Adv. 2015, 5, 57101-57113. [CrossRef]

60. David, A.; Meimoun, J.; Delaunay, T.; Wiatz, V.; Parcq, J.; Descamps, N. Structural characterization and mechanical properties of dextrin-graft-poly(butyl acrylate-co-styrene ) copolymers. Express Polym. Lett. 2019, 13, 235-247. [CrossRef] 
61. Sun, J.X.; Sun, X.F.; Sun, R.C.; Fowler, P.; Baird, M.S. Inhomogeneities in the Chemical Structure of Sugarcane Bagasse Lignin. J. Agric. Food Chem. 2003, 51, 6719-6725. [CrossRef] [PubMed]

62. Zhao, X.; Huang, Z.; Zhang, Y.; Yang, M.; Chen, D.; Huang, K.; Hu, H.; Huang, A.; Qin, X.; Feng, Z. Efficient solid-phase synthesis of acetylated lignin and a comparison of the properties of different modified lignins. J. Appl. Polym. Sci. 2017, 134, 1-13. [CrossRef]

63. Tobimatsu, Y.; Schuetz, M. Lignin polymerization: How do plants manage the chemistry so well? Curr. Opin. Biotechnol. 2019, 56, 75-81. [CrossRef] [PubMed]

64. Yang, W.; Rallini, M.; Wang, D.Y.; Gao, D.; Dominici, F.; Torre, L.; Kenny, J.M.; Puglia, D. Role of lignin nanoparticles in UV resistance, thermal and mechanical performance of PMMA nanocomposites prepared by a combined free-radical graft polymerization/masterbatch procedure. Compos. Part A Appl. Sci. Manuf. 2018, 107, 61-69. [CrossRef]

65. Marmur, A. Soft contact: Measurement and interpretation of contact angles. Soft Matter 2006, 2, $12-17$. [CrossRef]

66. Diraki, A.; Mackey, H.; Mckay, G.; Abdala, A.A. Chemical Engineering Research and Design Removal of oil from oil-water emulsions using thermally reduced graphene and graphene nanoplatelets. Chem. Eng. Res. Des. 2018, 137, 47-59. [CrossRef]

67. Bogdanova, Y.G.; Kostina, J.V.; Dolzhikova, V.D.; Chernikova, E.V.; Plutalova, A.V. Surface properties of poly(styrene-co-n-butyl acrylate) binary copolymers: Effect of chain microstructure and composition. Russ. J. Phys. Chem. A 2015, 89, 2466-2472. [CrossRef]

68. Santos, O.S.H.; Coelho da Silva, M.; Silva, V.R.; Mussel, W.N.; Yoshida, M.I. Polyurethane foam impregnated with lignin as a filler for the removal of crude oil from contaminated water. J. Hazard. Mater. 2017, 324, 406-413. [CrossRef]

69. Sousa Junior, R.R.d.; Gouveia, J.R.; Nacas, A.M.; Tavares, L.B.; Ito, N.M.; Moura, E.N.d.; Gaia, F.A.; Pereira, R.F.; Santos, D.J.d. Improvement of Polypropylene Adhesion by Kraft Lignin Incorporation. Mater. Res. 2019, 22, 1-8. [CrossRef]

70. Ma, Y.; Dai, J.; Wu, L.; Fang, G.; Guo, Z. Enhanced anti-ultraviolet, anti-fouling and anti-bacterial polyelectrolyte membrane of polystyrene grafted with trimethyl quaternary ammonium salt modified lignin. Polymer 2017, 114, 113-121. [CrossRef]

(C) 2019 by the authors. Licensee MDPI, Basel, Switzerland. This article is an open access article distributed under the terms and conditions of the Creative Commons Attribution (CC BY) license (http://creativecommons.org/licenses/by/4.0/). 